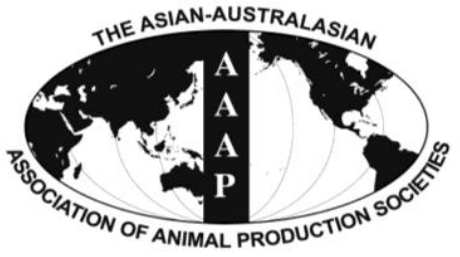

Asian Australas. J. Anim. Sci.

Vol. 26, No. 9 : 1262-1275 September 2013

http://dx.doi.org/10.5713/ajas.2012.12717

www.ajas.info

pISSN 1011-2367 elSSN 1976-5517

\title{
Use of Awamori-pressed Lees and Tofu Lees as Feed Ingredients for Growing Male Goats
}

\author{
Itsuki Nagamine, Katsunori Sunagawa*, and Takashi Kina \\ Faculty of Agriculture, University of the Ryukyus, 1 Senbaru, Nishihara-cho, Okinawa, 903-0213, Japan
}

\begin{abstract}
Awamori is produced by fermenting steamed indica rice. Awamori-pressed lees is a by-product of the Awamori production process. Tofu lees is a by-product of the Tofu production process. Research was conducted to test if dried Awamori-pressed lees and Tofu lees can be used as a mixed feed ingredient for raising male goats. Eighteen male kids were divided into three groups of six animals (control feed group (CFG), Awamori-pressed lees mixed feed group (AMFG), Tofu lees mixed feed group (TMFG)). The CFG used feed containing $20 \%$ soybean meal as the main protein source, while the AMFG and TMFG used feed mixed with $20 \%$ dried Awamori-pressed lees or dried Tofu lees. The groups were fed mixed feed (volume to provide $100 \mathrm{~g} / \mathrm{d}$ increase in body weight) and alfalfa hay cubes $(2.0 \mathrm{~kg} / \mathrm{d})$ twice a day $(10: 00,16: 00)$. Klein grass hay and water was given ad libitum. Hay intake was measured at 10:00 and 16:00. Body weight and size measurements were taken once a month. At the end of the experiment, a blood sample was drawn from the jugular vein of each animal and the carcass characteristics, the physical and chemical characteristics of loin were analyzed. DCP and TDN intakes in AMFG and TMFG showed no significant difference to the CFG. Cumulative measurements of growth in body weight and size over the 10 mo period in the AMFG and TMFG were similar to the CFG. Blood parameter values were similar to those in normal goats. Dressing carcass weight and percentages, and total weight of meat in the AMFG were similar to that in the CFG, but smaller in the TMFG. The compressed meat juice ratio was higher in both the TMFG and AMFG than the CFG. While the fat in corn, Awamori-pressed lees, and Tofu lees contains more than 50\% linoleic acid, the loin fat in both the AMFG and TMFG was very low in linoleic acid due to the increase in the content of oleic acid, stearic acid, and palmitic acid. This indicates that feeding on AMF and TMF does not inhibit hydrogenation by ruminal microorganisms. As in the CFG, the total essential and non-essential amino acids in the loin of the AMFG and TMFG were well balanced. Compared to the CFG, the AMFG and TMFG were high in taurine and carnosine. The results indicate dried Awamori-pressed lees and Tofu lees can be used as a feed ingredient for raising male goats. (Key Words: Awamori-pressed Lees, Tofu Lees, Growth, Body Size, Meat Production, Male Goat)
\end{abstract}

\section{INTRODUCTION}

The rumino-reticulum of newly weaned kid goats and calves does not have the capacity or digestive function of mature animals (Lengemann and Allen, 1955) and therefore it is difficult for them to meet their nutritional needs from grass alone. In order for them to grow at normal rates, they must also be fed highly concentrated feed. At present the main ingredient of such feeds is corn, soy bean meal, and wheat bran which are used to create formulated concentrate feed. Decreased production of crops used in mixed feed due to recent climatic changes, droughts and floods, and increased demand for the same crops by the bio-ethanol industry has caused a rise in the world price of grains (FAO,

\footnotetext{
* Corresponding Author: K. Sunagawa. Tel: +81-98-895-8798, Fax: +81-98-895-8734, E-mail: b986094@agr.u-ryukyu.ac.jp Submitted Dec. 27, 2012; Accepted Apr. 4, 2013; Revised May 17, 2013
}

2008; Scott et al., 2009). The rise in grain prices has had a profound effect on the management of meat producing farms in countries reliant on imported feed such as Japan. Thus, the utilization of imported grain is decreasing and there is an urgent need to develop locally produced feed sources of low cost. We are focusing our attention on food by-products as an alternative to traditional imported feed.

Okinawan Awamori is produced by fermenting steamed indica rice with black mold, yeast, and water. Awamoripressed lees is a by-product of the Awamori production process. Awamori-pressed lees are soft, highly viscous with low water content $(54 \%)$ and contain a high amount of nutritional and functional components. There are approximately 30,000 tons of Awamori-pressed lees produced each year that are being disposed of as waste. The lees are high in protein and spoil easily which make them incompatible for use as feed and thus they are disposed of as industrial waste. In Okinawa, Tofu is made from soy 
milk and the by-product of the pressing and squeezing process is known as Tofu lees. Each year in Okinawa, approximately 800,000 tons of Tofu lees are disposed of due to the fact that its high water and protein content makes it incompatible for use as feed. Thus the majority of the lees are treated as industrial waste. These lees are rich in nutritional components including protein, lipids, calcium, and bioactive functional components such as isoflavone, $\gamma$-aminobutyric acid (GABA), polyphenol, and citric acids (Inada et al., 2003; Genovese et al., 2006; Takaya et al., 2007). Because of this, it is thought that both Awamoripressed lees and Tofu lees are capable of being used as feed ingredients, and in particular, as a source of protein.

Fujitani et al. (2000) reported that Holstein steers fed on a diet of full-fat rice bran mixed with Tofu lees gained equal amounts of weight as a control group fed on control feed. Tamaki et al. (2005) fed Holstein milking cows for $6 \mathrm{wk}$ on a diet of feed mixed with $3 \%$ soy bean meal, and feed mixed with $3 \%$ Awamori-pressed lees. The result was that there was no significant difference between the two feeds in terms of dry matter intake, body weight, and lactation performance. It is therefore reported that Awamori-pressed lees can be used as a substitute for soy bean meal in feed. However, the amount of Awamori-pressed lees and Tofu lees combined with basal feed was low, the length of time the mixed feed was supplied was short, and only body weight was measured in these reports. Consequently, it is unclear as to whether or not lees can be used as a source of feed for growing ruminants.

The aim of this research was to demonstrate that Awamori-pressed lees and Tofu lees can be used as feed ingredients for rearing kid goats during growth periods and these lees do not affect meat quality.

\section{MATERIALS AND METHODS}

\section{Animals}

Eighteen male kid goats (crossbred Japanese Saanen/Nubian goats, approximately 3 mo age, mean \pm SD of BW: $13.3 \pm 3.22 \mathrm{~kg}$ ) were used in this experiment. Saanen goats trace their origin to Swizerland and are now found throughout the world. By contrast, the Nubian breed originates in Africa and is widely found throughout tropical and sub-tropical regions. All of the animals used in this experiment were crossbred (F1) from these two breeds. The animals were housed in three indoor farm pens (six animals per pen) during both the preparatory feeding period and the experimental period.

Production of experimental diet mixed with Awamoripressed lees or Tofu lees

The Awamori-pressed lees were dried at $70^{\circ} \mathrm{C}$ for $8 \mathrm{~h}$ and then powdered to form an ingredient in the mixed feed
Table 1. Chemical composition of dried Awamori-pressed lees and dried Tofu lees

\begin{tabular}{|c|c|c|}
\hline & $\begin{array}{c}\text { Dried } \\
\text { Awamori-pressed } \\
\text { lees }\end{array}$ & $\begin{array}{c}\text { Dried Tofu } \\
\text { lees }\end{array}$ \\
\hline Dry matter $(\%)$ & 97.9 & 91.8 \\
\hline \multicolumn{3}{|c|}{ Chemical composition (\% DM) } \\
\hline Crude protein & 46.1 & 28.6 \\
\hline Ether extracts & 15.7 & 14.3 \\
\hline Crude fiber & 12.8 & 16.1 \\
\hline Crude ash & 0.9 & 4.6 \\
\hline Nitrogen free extracts & 24.5 & 36.4 \\
\hline
\end{tabular}

used in the experiments. Tofu lees used in the mixed feed were first subjected to $24 \mathrm{~h}$ of air-oven drying at $70^{\circ} \mathrm{C}$. The chemical composition of dried Awamori-pressed lees and dried Tofu lees were shown in Table 1.

The three types of feed (control feed (CF), 20\% Awamori-pressed lees mixed feed (AMF), 20\% Tofu lees mixed feed (TMF), Table 2) made for use in this experiment were produced using the TDN and DCP values of Awamoripressed lees and Tofu lees that were elucidated previously (Nagamine et al., 2012). The mixed feeds were produced to ensure that the DCP and TDN for all three feed types were virtually equal (Table 3). The formulated mixed feed for calves has used to rear the goats on the farm. Therefore, the feeds were designed to provide DCP and TDN levels similar to that offered in calf formulated mixed feed currently available in the market.

\section{Experimental design}

The eighteen animals used in the experiment were separated into three groups of six animals (control group (CFG), Awamori-pressed lees group (AMFG), Tofu lees group (TMFG)). The body weight (mean \pm SD) of the animals in CFG, AMFG and TMFG were 13.3 \pm 4.52 , $13.3 \pm 2.94$ and $13.3 \pm 2.50$ at the start of experiment. The

Table 2. Ingredients of control feed (CF), Awamori-pressed lees mixed feed (AMF) and Tofu lees mixed feed (TMF)

\begin{tabular}{lrrr}
\hline Ingredients & CF & AMF & TMF \\
\hline Wheat bran & 27.1 & 18.1 & 21.5 \\
Rolled corn & 43.0 & 42.0 & 35.0 \\
Alfalfa meal & 9.5 & 4.3 & 9.5 \\
Soy bean meal & 20.0 & 15.2 & 13.6 \\
Dried Tofu lees & 0.0 & 0.0 & 20.0 \\
Dried Awamori-pressed lees & 0.0 & 20.0 & 0.0 \\
Vitamin-mineral premix $^{1}$ & 0.3 & 0.3 & 0.3 \\
CaCO $_{3}$ & 0.1 & 0.1 & 0.1 \\
Total & 100 & 100 & 100 \\
\hline
\end{tabular}

${ }^{1}$ Vitamin-mineral premix contained (DM basis): $2,511 \mathrm{mg} / \mathrm{kg} \mathrm{Fe} ; 750$ $\mathrm{mg} / \mathrm{kg} \mathrm{Cu} ; 250 \mathrm{mg} / \mathrm{kg} \mathrm{Mn} ; 2,501 \mathrm{mg} / \mathrm{kg} \mathrm{Zn} ; 50,000 \mathrm{mg} / \mathrm{kg}$ Choline chloride; 1,000,000 IU/kg VA; $150,000 \mathrm{IU} / \mathrm{kg} \mathrm{VD} ; 300 \mathrm{mg} / \mathrm{kg} \mathrm{VB}$; $1,000 \mathrm{mg} / \mathrm{kg} \mathrm{VB}{ }_{2} ; 1,300 \mathrm{mg} / \mathrm{kg} \mathrm{VB} ; 31,100 \mathrm{mg} / \mathrm{kg} \mathrm{VB}{ }_{5} ; 600 \mathrm{mg} / \mathrm{kg} \mathrm{VB} 6$; $125 \mathrm{mg} / \mathrm{kg} \mathrm{VB} ; ; 1.5 \mathrm{mg} / \mathrm{kg} \mathrm{VB}{ }_{12} ; 5,000 \mathrm{mg} / \mathrm{kg} \mathrm{VE}$; and $267 \mathrm{mg} / \mathrm{kg} \mathrm{VK}$. 
Table 3. Chemical composition of control feed (CF), Awamoripressed lees mixed feed (AMF) and Tofu lees mixed feed (TMF)

\begin{tabular}{lrrr}
\hline & CF & AMF & TMF \\
\hline Dry matter (\%) & 84.8 & 88.3 & 86.9 \\
Chemical composition (\% DM) & & & \\
$\quad$ Crude protein & 20.5 & 24.7 & 21.3 \\
Ether extracts & 3.5 & 6.0 & 5.7 \\
Crude fiber & 6.3 & 6.8 & 8.6 \\
Crude ash & 5.5 & 4.4 & 5.4 \\
Nitrogen free extracts & 64.2 & 58.1 & 59.0 \\
DCP* & 17.5 & 17.6 & 17.7 \\
TDN* & 77.7 & 77.2 & 77.0 \\
\hline
\end{tabular}

* DCP and TDN values were calculated using mixed percentage and digestibility of each ingredient.

animals were fed mixed feed and alfalfa hay cubes twice a day (10:00 h, 16:00 h). Klein grass hay was fed ad libitum. The alfalfa hay cubes $(84.30 \%$ dry matter (DM)) contained, on a DM basis, $18.7 \%$ crude protein $(\mathrm{CP}), 2.4 \%$ crude fat, $29.7 \%$ crude fiber, $39.7 \%$ nitrogen-free extracts (NFE). The klein grass hay $(92.8 \%$ dry matter (DM)) contained, on a DM basis, $8.4 \%$ crude protein (CP), $1.6 \%$ crude fat, $31.0 \%$ crude fiber, $50.3 \%$ nitrogen-free extracts (NFE). The animals were all given free access to water.

The amount of feed given to the animals was designed to provide a $100 \mathrm{~g} / \mathrm{d}$ increase in body weight based on NRC feeding standards (NRC, 2006). The amount of mixed feed given to the animals in each group (CFG, AMFG and TMFG) was $2,400 \mathrm{~g}$ on a fresh matter (FM) basis for the first 3 mo. Following this period, the allocation was increased 3,000 g FM. The amount of crushed alfalfa hay cubes given was $875 \mathrm{~g} \mathrm{DM} / 6$ head from 3 to $4 \mathrm{mo}, 1,604.2$ $\mathrm{g} \mathrm{DM} / 6$ head at $4 \mathrm{mo}$ and 1,750 g DM/6head after 5 mo (Table 4). The mixed feed and crushed alfalfa hay cubes given to the animals was completely consumed within one hour. Following this, Klein grass hay was supplied in sufficient quantities so as to ensure remaining grass once the animals were completely satiated. The consumed amount was determined by subtracting the remaining grass from the given to the animals.

Over the 10 mo of the experiment, the index of growth of the animals was determined by monthly measurements of body weight, length, withers height, hip height, chest depth, width, girth, and hip width. Body weight was determined using a set of scales (Iconix New Zealand Ltd, New Zealand), chest girth was measured using a measuring tape, and the remainder of the measurements was determined using a body size measurement apparatus (Fujihira Kougyou, Tokyo). A blood sample was taken from the jugular vein using plastic syringe on the last day of the experiment in order to analyze blood parameters. Following the experiment, all animals were slaughtered, and the physical and the chemical characteristics of the carcass and loin meat were analyzed.

\section{Chemical analysis of feed}

Chemical composition of dried Awamori-pressed lees, dried Tofu lees, CF, AMF, and TMF was measured using previously mentioned methods (Thang et al., 2012).

\section{Biochemical analysis of blood composition}

Hematocrit, plasma osmolality, and plasma concentrations of total protein, albumin glucose, $\mathrm{Na}, \mathrm{K}, \mathrm{Cl}$ and lipids were measured using same method as that adopted by Thang et al. (2012).

\section{Analysis of the carcass}

The animal's body was washed once the hair had been removed with a burner. The head and internal organs were removed and the carcass was cut in two along the spine with an electric saw. The dressing percentage is calculated by dividing the dressed carcass weight by the live weight of the animal upon the conclusion of the experiment (13 months post-partum).

The dressed carcass was divided in 5 cuts including Chuck, Brisket, Loin, Plate and Flank, and Round (Figure 1). The weight of the cuts was measured once the bone had been removed. The rib-eye area was measured as the transverse plane of the longissimus thoracis between the 6th and 7 th ribs. A planimeter (Planix EX, Tamaya Technics Inc., Tokyo) was used to measure the rib-eye area. The

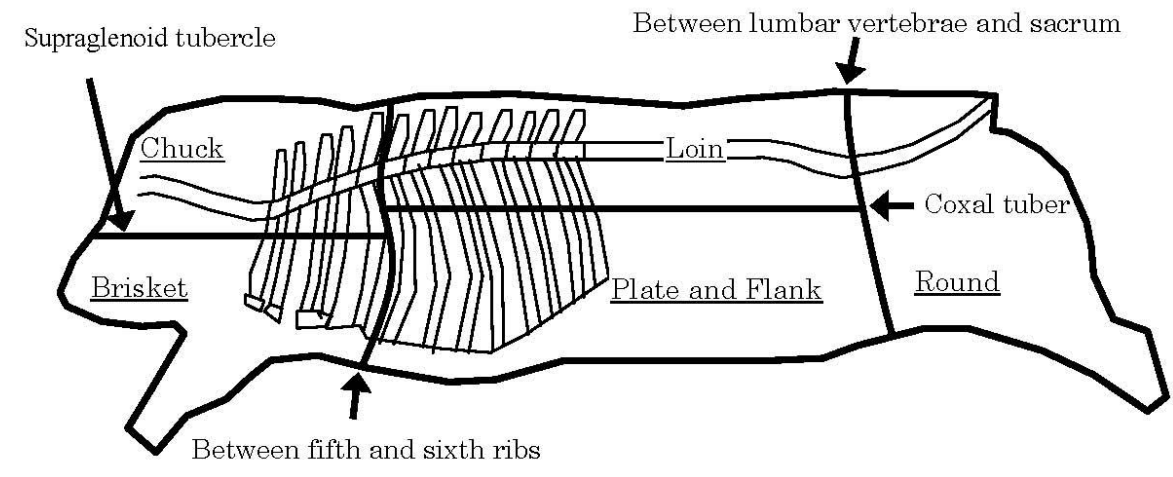

Figure 1. Division of goat dressing: The dressing was divided into five area. 
average of three measurements was used to represent the area.

Once the contents had been removed, the weight of rumen, reticulum, omasum, abomasum, large and small intestines, liver, heart, spleen, lungs, and trachea was measured. The length of the small and large intestines was also measured using a measuring tape.

\section{Analysis of the physical characteristics in longissimus thoracis}

Cooking loss, tenderness, water holding capacity and compressed meat juice ratio were measured as indexes of meat juice retention, tenderness, water retention and juiciness in meat.

Measurement of cooking loss: Fifty grams of loin were cut and weighed (A), and then sealed in a plastic bag to keep out surrounding water. This was warmed in warm water $\left(70^{\circ} \mathrm{C}\right)$ and cooled for $30 \mathrm{~min}$ with running water. After cooling, the weight of sample was measured (B).

Cooking loss was calculated by the following formula.

Cooking loss $(\%)=\{(\mathrm{A}-\mathrm{B}) / \mathrm{A}\} \times 100$

Measurement of tenderness: Following the measurement of cooking loss, the loin was cut in pieces $1 \mathrm{~cm}$ in thickness. This was set in the Tensipresser (TTP-50BXII, Taketomo Electric, Tokyo) to which a plunger (o.d. $5.5 \mathrm{~mm}$, i.d. 5.0 $\mathrm{mm}$, area $0.041 \mathrm{~cm}^{2}$, aerial and round) was attached. Meat was sheared by the plunger at a velocity of $2 \mathrm{~mm} / \mathrm{s}$. Pressure at the point of rupture was recorded.

Measurement of water holding capacity: $0.5 \mathrm{~g}$ of cubical loin was put on the center of filter paper. This was wedged between two acrylic plates and placed under pressure for 1 min at $35 \mathrm{~kg} / \mathrm{cm}^{2}$ with the pressure device. After that, the areas of meat and meat juice that oozed out on to the filter paper were measured using a planimeter (Planix EX, Tamaya Technics Inc., Tokyo).

Water holding capacity was calculated by the following formula.

Water holding capacity

$=[1-\{($ meat juice area-meat area $)$

$\times 9.47 /$ moisture content of meat $(\mathrm{mg})\}] \times 100$

Measurement of compressed meat juice ratio: $0.5 \mathrm{~g}$ of cubical weighed loin was wedged between two membrane filters (Millipore $0.45 \mu \mathrm{m}$ ), two gauzes with cotton and two filter papers (Adventec, 5A). This was wedged between two acrylic plates and pressured for $1 \mathrm{~min}$ at $35 \mathrm{~kg} / \mathrm{cm}^{2}$ with the pressure device. After that, the meat attached membrane filter was removed and weight of meat was measured.

Compressed meat juice ratio was calculated by the following formula.

Compressed meat juice ratio

$=\{$ (weight before pressure-weight after pressure $)$ /weight before pressure $\} \times 100$

\section{Measurement of chemical property in longissimus thoracis}

Total lipid content, melting point of fat, composition of fatty acids, and concentration of free amino acids were measured.

Measuring melting point of fat: The melting point of fat extracted from a sample of approximately $20 \mathrm{~g}$ of hashed loin meat was measured according to the slip melting point method. The temperatures of seven analytes were recorded per sample and averaged. The mean value was shown as melting point $\left({ }^{\circ} \mathrm{C}\right)$ of fat in the sample.

Measurement of total lipids content and fatty acids composition: One gram of minced loin meat was homogenized with a 2:1 chloroform-methanol mixture (v/v) to extract lipids (Folch et al., 1957). Weight of extracted lipid was measured to obtain total lipids content. The lipid extract $(0.03 \mathrm{~g})$ was saponified, and the fatty acid was extracted. The fatty acids methyl ester was dissolved in acetone, and $1 \mu \mathrm{L}$ of this solution was injected into a gas chromatograph (GLC, G-3000, Hitachi, Tokyo). Retention time of samples' peak detected was compared with that of a methyl ester standard of fatty acid, and fatty acids were identified. Also, ratio of each fatty acid was calculated from the peak area. The column used in the present study was a dual glass column (i.d $3 \mathrm{~mm}, 2.45 \mathrm{~m}$ length) and packing materials were Silar 10C (coating Gaschrom Q with Silar 10C at 5\%, 80-100 mesh, Shimazu GLC, Tokyo). Condition for determination was column temperature $156^{\circ} \mathrm{C}$, injector temperature $275^{\circ} \mathrm{C}$, detector temperature $275^{\circ} \mathrm{C}, \mathrm{N}_{2}$ flow rate $40.0 \mathrm{~mL} / \mathrm{min}, \mathrm{H}_{2}$ pressure of hydrogen flame ionization detector (FID) $1.5 \mathrm{~kg} / \mathrm{cm}^{2}$ and air pressure $1.0 \mathrm{~kg} / \mathrm{cm}^{2}$. The rising temperature program began $5 \mathrm{~min}$ after sample injection and continued at a velocity of $2^{\circ} \mathrm{C} / \mathrm{min}$ until the temperature reached $240^{\circ} \mathrm{C}$.

Measurement of free amino acids concentration: Ten gram of minced loin meat was homogenized with ethanol (4.0-fold volume of meat), and then it was filtrated using a glass filter (3G3). Filtrate was put into a pear-shaped flask and was evaporated and concentrated with a rotary evaporator. N-hexane was added and fat removal was repeated. Ten milliliter of distilled water was added to the dried residue obtained and centrifuged at 10,000 RPM for $30 \mathrm{~min}$. The supernatant solution was dried and dissolved in sodium citrate buffer ( $\mathrm{pH} 2.2)$, and then filtered using 0.45 $\mu \mathrm{m}$ filter for free amino acids analysis. Amino acid standard solution was a mixture of commercial amino acid standard solution (WAKO, Type H, containing 17 amino acids), 0.1 
$\mathrm{mol} / \mathrm{L}$ glutamine- $\mathrm{NaOH}$ solution, $0.1 \mathrm{~mol} / \mathrm{L}$ asparagine$\mathrm{NaOH}$ solution, $0.1 \mathrm{~mol} / \mathrm{L} \quad \gamma$-aminobutyric acid-NaOH solution, $0.1 \mathrm{~mol} / \mathrm{L}$ taurine- $\mathrm{HCl}$ solution, $0.1 \mathrm{~mol} / \mathrm{L}$ ornithine- $\mathrm{HCl}$ solution, $0.1 \mathrm{~mol} / \mathrm{L}$ anserine- $\mathrm{HCl}$ solution and $0.1 \mathrm{~mol} / \mathrm{L}$ carnosine- $\mathrm{HCl}$ solution. Sodium citrate buffer was prepared as follows. Trisodium citrate dehydrate (9.8 g), perchloric acid $(8 \mathrm{~mL}), \mathrm{n}$-caprylic acid $(0.05 \mathrm{~mL})$ were dissolved in double-distilled water. The $\mathrm{pH}$ was adjusted at $\mathrm{pH} 2.2$ using perchloric acid and the volume brought up to $500 \mathrm{~mL}$ with double-distilled water. Quantitative determination of amino acid was carried out using a high-performance liquid chromatograph (HPLC, LC-6A, Shimadzu, Kyoto, Japan). Amino acid assay was performed according to post column method with ophthaldialdehyde (OPA, WAKO, amino acid analysis grade). That is, contaminating substances were removed using a guard column (ISC-07NA, $50 \times 4.0 \mathrm{~mm}$ i.d.) and analysis of derivatives of amino group and OPA was continued with a post column (Shim-pack ISC-07/S1504 Na, $7 \mu \mathrm{m}, 150 \times 4.0$ mm i.d.) (Godel et al., 1984; Qureshi et al., 1984). Condition for determination was as follows.

i) Mobile phase

Flow rate: $0.3 \mathrm{~mL} / \mathrm{min}$

Solution 1: Trisodium citrate dihydrate $58.8 \mathrm{~g}, 210 \mathrm{~mL}$ of ethanol and $50 \mathrm{~mL}$ of $60 \%$ perchloric acid were dissolved in $3 \mathrm{~L}$ of double-distilled water.

Solution 2: Trisodium citrate dihydrate $58.8 \mathrm{~g}$, boric acid (Wako, amino acid analysis grade) $12.4 \mathrm{~g}$ and $30 \mathrm{~mL}$ of $4 \mathrm{~N}$ sodium hydroxide solution were dissolved in $1 \mathrm{~L}$ of double-distilled water.

Gradient: Under the condition that total flow rate of mobile phase was maintained at $0.3 \mathrm{~mL} / \mathrm{min}$, decreased flow rate of solution 1 and increased flow rate of solution 2 was performed simultaneously. By doing so, mixing ratio of solution 1 and 2 was varied.

Washing solution: Sodium hydroxide $4 \mathrm{~g}$ was dissolved in $0.5 \mathrm{~L}$ of double-distilled water.

ii) Reaction solution

Flow rate: $0.2 \mathrm{~mL} / \mathrm{min}$

Borate-carbonate buffer ( $\mathrm{pH}$ 10.0): $\mathrm{Na}_{2} \mathrm{CO}_{3} 122.1 \mathrm{~g}$, $\mathrm{H}_{3} \mathrm{BO}_{3} 40.7 \mathrm{~g}$ and $\mathrm{K}_{2} \mathrm{SO}_{4} 56.4 \mathrm{~g}$ were dissolved in $3 \mathrm{~L}$ of double-distilled water.

Solution A: $0.2 \mathrm{~mL}$ of sodium hypochlorite (Wako, chemical grade) was dissolved in $0.5 \mathrm{~L}$ of borate-carbonate buffer.

Solution B: OPA $400 \mathrm{mg}, 7.0 \mathrm{~mL}$ of ethanol, $1.0 \mathrm{~mL}$ of 2-mercaptoethanol (Wako, biochemical grade) and $2 \mathrm{~mL}$ of $10 \%$ Brij-35 (polyoxyethylene laurylether) were dissolved in $0.5 \mathrm{~L}$ of borate-carbonate buffer.

iii) Column: temperature $55^{\circ} \mathrm{C}$ iv) Sample injection volume : $10 \mu \mathrm{L}(1 \mathrm{nmol}$ amino acid $)$

v) Shimadzu fluorescence detector (RF-530 spectoromonitor) exitation wavelength $348 \mathrm{~nm}$, emission wavelength $450 \mathrm{~nm}$

\section{Statistical analysis}

In this experiment, because six animals were reared in one pen, the amount of hay consumed by all six animals combined was recorded as the daily hay intake.

Body measurement, blood parameter and meat parameter values are shown as a mean value of the 6 animals in the group. A one-way analysis of variance and a subsequent Duncan's multiple range test were used to compare the cumulative increase in the daily intake of hay, body measurement parameters, blood parameters and meat parameters with the individual feed groups. For statistical analysis, GLM procedure (SAS, 1990) was used.

All data were analyzed using the following model:

$$
\mathrm{Y}_{\mathrm{ij}}=\mu+\mathrm{T}_{\mathrm{i}}+\varepsilon_{\mathrm{ij}}
$$

Where $Y_{\mathrm{ij}}=$ the measured variable; $\mu=$ the overall mean; $\mathrm{T}_{\mathrm{i}}=$ the effect of the $\mathrm{i}^{\text {th }}$ treatment; $\varepsilon_{\mathrm{ij}}=$ the random error effect.

\section{RESULTS}

\section{The palatability and the nutritive value of mixed feed}

Table 4 shows daily intake of mixed feeds (CF, AMF, TMF). The feed intake in the CFG between 3 to 4 mo old was 2,061.6 $\mathrm{g} \mathrm{DM} / 6 \mathrm{head} / \mathrm{d}$ and then 2,577.0 $\mathrm{g} \mathrm{DM} / 6$ head/d from 5 mo of age. The feed intake in the AMFG between 3 to 4 mo old was 2,119.2 g DM/ 6 head/d and then 2,649.0 $\mathrm{g} \mathrm{DM} / 6 \mathrm{head} / \mathrm{d}$ from 5 mo of age. The feed intake in the TMFG between 3 to 4 mo old was 2,085.6 $\mathrm{g} \mathrm{DM} / 6$ head/d and then 2,607.0 g DM/6 head/d from 5 mo of age. As with $\mathrm{CF}$, the palatability of the AMF and TMF was high. As was the case with the CF, the AMF and TMF feeds were completely consumed in under an hour.

The amount of hay consumed by AMFG and TMFG progressively increased over time and was particularly evident at 4, 9, 10 mo of age. This was similar to the CFG. The amount of hay being consumed by the groups at $13 \mathrm{mo}$ of age when the experiment was concluded had reached 502 $\mathrm{g} / \mathrm{head} / \mathrm{d}$. During the experiment, the amount of hay consumed in the AMFG, TMFG and the CFG was virtually equal.

The TDN and DCP intakes of the groups were calculated from mixed feeds, alfalfa hay cubes and hay intakes. The TDN and DCP intake of the groups in the CFG, AMFG, and TMFG met the nutrient requirements for growing female goats as specified in the NRC feeding 
Table 4. Effect of feeding Awamori-pressed lees mixed feed (AMF) and Tofu lees mixed feed (TMF) on hay intake

\begin{tabular}{|c|c|c|c|c|c|}
\hline \multirow{2}{*}{ Month age $^{1}$} & \multicolumn{3}{|c|}{ Mixed feed $^{2}(\mathrm{~g} \mathrm{DM} / 6$ head/d $)$} & \multirow{2}{*}{$\begin{array}{l}\text { Alfalfa hay cubes }{ }^{3} \\
(\mathrm{~g} \mathrm{DM} / 6 \mathrm{head} / \mathrm{d})\end{array}$} & \multirow{2}{*}{$\begin{array}{l}\text { Klein grass hay } \\
(\mathrm{g} \mathrm{DM} / 6 \mathrm{head} / \mathrm{d})\end{array}$} \\
\hline & $\mathrm{CFG}^{4}$ & $\mathrm{AMFG}^{5}$ & TMFG $^{6}$ & & \\
\hline $3-4$ & $2,061.6$ & $2,119.2$ & $2,085.6$ & 875.0 & 185.6 \\
\hline $4-5$ & $2,061.6$ & $2,119.2$ & $2,085.6$ & 875.0 & 593.9 \\
\hline $5-6$ & $2,577.0$ & $2,649.0$ & $2,607.0$ & $1,604.2$ & 928.0 \\
\hline $6-7$ & $2,577.0$ & $2,649.0$ & $2,607.0$ & $1,750.0$ & 928.0 \\
\hline $7-8$ & $2,577.0$ & $2,649.0$ & $2,607.0$ & $1,750.0$ & 928.0 \\
\hline $8-9$ & $2,577.0$ & $2,649.0$ & $2,607.0$ & $1,750.0$ & $1,020.8$ \\
\hline $9-10$ & $2,577.0$ & $2,649.0$ & $2,607.0$ & $1,750.0$ & $1,856.0$ \\
\hline $10-11$ & $2,577.0$ & $2,649.0$ & $2,607.0$ & $1,750.0$ & $2,474.7$ \\
\hline $11-12$ & $2,577.0$ & $2,649.0$ & $2,607.0$ & $1,750.0$ & $2,784.0$ \\
\hline $12-13$ & $2,577.0$ & $2,649.0$ & $2,607.0$ & $1,750.0$ & $3,016.0$ \\
\hline
\end{tabular}

${ }^{1}$ Age of animals.

${ }^{2}$ Amount of each mixed feed (control feed, Awamori-pressed lees mixed feed, Tofu lees mixed feed) that was fed to gain $100 \mathrm{~g}$ per day.

${ }^{3}$ Because six animals were reared in one pen, the amount of hay consumed by all six animals combined was recorded as the daily hay cube and hay intake. The mean and SEM of daily hay cube and hay intakes per pen in each month (30 d) are shown.

${ }^{4}$ Control feed group. ${ }^{5}$ Awamori-pressed lees mixed feed group. ${ }^{6}$ Tofu lees mixed feed group.

Means of AMFG and TMFG in the same row are significantly different from CFG $(\mathrm{p}<0.05)$.

standards (NRC, 2006; Table 5).

Effects of feeding Awamori-pressed lees mixed feed and Tofu lees mixed feed on growth

Table 6 shows the monthly body weight and size measurements of the animals in all three feed groups (CFG, AMFG, TMFG). During the experiment, monthly body weight in the AMFG and TMFG were approximately the same as the CFG. Monthly measured values of withers height, hip height, chest depth, chest width, chest girth and hip width in the AMFG and TMFG were similar to the CFG during the experiment. By contrast, while there was no significant difference in monthly measured body length between the TMFG and CFG, that in the AMFG after 5 mo of age tended to be longer than the CFG.

Table 7 shows the cumulative growth of the animals during the 10 month experimental period. Cumulative withers height, body length and hip height in the AMFG

Table 5. Total digestible nutrients (TDN) and digestible crude protein (DCP) intake levels in the CFG, AMFG, and TMFG

\begin{tabular}{|c|c|c|c|c|c|c|c|c|c|c|c|}
\hline \multirow{2}{*}{ Parameter } & \multirow{2}{*}{ Feed } & \multicolumn{10}{|c|}{ Age in month } \\
\hline & & 3 & 4 & 5 & 6 & 7 & 8 & 9 & 10 & 11 & 12 \\
\hline \multicolumn{12}{|c|}{ Total digestible nutrients (TDN) intake } \\
\hline \multirow{3}{*}{$\begin{array}{l}\text { Required } \\
\qquad(\mathrm{g} \mathrm{DM} / 6 \mathrm{head} / \mathrm{d})\end{array}$} & $\mathrm{CFG}^{1}$ & $2,140.0$ & $2,361.6$ & $2,603.9$ & $2,855.7$ & $3,023.5$ & $3,198.9$ & $3,455.3$ & $3,610.0$ & $4,012.6$ & $4,186.0$ \\
\hline & $\mathrm{AMFG}^{2}$ & $2,141.9$ & $2,335.2$ & $2,616.2$ & $2,896.2$ & $3,104.6$ & $3,315.8$ & $3,525.1$ & $3,757.0$ & $4,113.4$ & $4,222.8$ \\
\hline & $\mathrm{TMFG}^{3}$ & $2,140.0$ & $2,332.4$ & $2,564.3$ & $2,863.2$ & $3,004.6$ & $3,161.2$ & $3,336.5$ & $3,630.7$ & $4,007.8$ & $4,216.2$ \\
\hline \multirow{3}{*}{$\begin{array}{l}\text { Intake } \\
(\text { g DM/6 head/d })\end{array}$} & CFG & $2,178.0$ & $2,410.7$ & $3,402.0$ & $3,482.8$ & $3,482.8$ & $3,535.6$ & $4,011.7$ & $4,364.4$ & $4,540.7$ & $4,672.9$ \\
\hline & AMFG & $2,222.3$ & $2,455.1$ & $3,457.4$ & $3,538.2$ & $3,538.2$ & $3,591.1$ & $4,067.2$ & $4,419.8$ & $4,596.1$ & $4,728.4$ \\
\hline & TMFG & $2,200.6$ & $2,433.4$ & $3,430.3$ & $3,511.1$ & $3,511.1$ & $3,564.0$ & $4,040.0$ & $4,392.7$ & $4,569.0$ & $4,701.2$ \\
\hline \multirow[t]{3}{*}{ Adequacy (\%) } & CFG & 101.8 & 102.1 & 130.6 & 122.0 & 115.2 & 110.5 & 116.1 & 120.9 & 113.2 & 111.6 \\
\hline & AMFG & 103.8 & 105.1 & 132.2 & 122.2 & 114.0 & 108.3 & 115.4 & 117.6 & 111.7 & 112.0 \\
\hline & TMFG & 102.8 & 104.3 & 133.8 & 122.6 & 116.9 & 112.7 & 121.1 & 121.0 & 114.0 & 111.5 \\
\hline \multicolumn{12}{|c|}{ Digestible crude protein (DCP) intake } \\
\hline \multirow{3}{*}{$\begin{array}{l}\text { Required } \\
(\text { g DM/6 head/d) }\end{array}$} & CFG & 189.9 & 210.4 & 232.7 & 256.0 & 271.5 & 287.7 & 311.4 & 325.7 & 362.9 & 379.0 \\
\hline & AMFG & 190.1 & 207.9 & 233.9 & 259.8 & 279.0 & 298.5 & 317.9 & 339.3 & 372.3 & 382.4 \\
\hline & TMFG & 189.9 & 207.7 & 229.1 & 256.7 & 269.8 & 284.2 & 300.5 & 327.6 & 362.5 & 381.8 \\
\hline \multirow{3}{*}{$\begin{array}{l}\text { Intake } \\
(\mathrm{g} \mathrm{DM} / 6 \text { head/d) }\end{array}$} & CFG & 595.6 & 718.1 & $1,055.4$ & $1,084.5$ & $1,084.5$ & $1,112.4$ & $1,362.9$ & $1,548.5$ & $1,641.3$ & $1,710.9$ \\
\hline & AMFG & 605.8 & 728.3 & $1,068.1$ & $1,097.3$ & $1,097.3$ & $1,125.1$ & $1,375.7$ & $1,561.3$ & $1,654.1$ & $1,723.3$ \\
\hline & TMFG & 599.8 & 722.3 & $1,060.7$ & $1,089.8$ & $1,089.8$ & $1,117.7$ & $1,368.2$ & $1,553.8$ & $1,646.6$ & $1,716.2$ \\
\hline \multirow[t]{3}{*}{ Adequacy (\%) } & CFG & 313.7 & 341.4 & 453.4 & 423.6 & 399.4 & 386.6 & 437.6 & 475.4 & 452.2 & 451.5 \\
\hline & AMFG & 318.7 & 350.3 & 456.7 & 422.4 & 393.3 & 376.9 & 432.8 & 460.1 & 444.3 & 450.8 \\
\hline & TMFG & 315.9 & 347.9 & 463.0 & 424.5 & 404.0 & 393.2 & 455.4 & 474.2 & 454.2 & 449.6 \\
\hline
\end{tabular}

Values are mean of TDN and DCP required level, intake level and adequacy per group in each month (30 d).

${ }^{1}$ Control feed group. ${ }^{2}$ Awamori-pressed lees mixed feed group. ${ }^{3}$ Tofu lees mixed feed group. 
Table 6. Effect of feeding Awamori-pressed lees mixed feed (AMF) and Tofu lees mixed feed (TMF) on the growth of male goats

\begin{tabular}{|c|c|c|c|c|c|c|c|c|c|c|c|c|}
\hline \multirow{2}{*}{ Parameter } & \multirow{2}{*}{ Feed } & \multicolumn{11}{|c|}{ Age in month } \\
\hline & & 3 & 4 & 5 & 6 & 7 & 8 & 9 & 10 & 11 & 12 & 13 \\
\hline \multirow{4}{*}{$\begin{array}{l}\text { Body weight } \\
(\mathrm{kg})\end{array}$} & $\mathrm{CFG}^{1}$ & 13.3 & 17.2 & 21.5 & 25.9 & 28.9 & 32.0 & 36.5 & 39.3 & 46.4 & 49.5 & 52.4 \\
\hline & $\mathrm{AMFG}^{2}$ & 13.3 & 16.7 & 21.7 & 26.7 & 30.3 & 34.1 & 37.8 & 41.9 & 48.2 & 50.1 & 52.8 \\
\hline & $\mathrm{TMFG}^{3}$ & 13.3 & 16.7 & 20.8 & 26.1 & 28.6 & 31.3 & 34.4 & 39.6 & 46.3 & 50.0 & 52.3 \\
\hline & SEM $^{4}$ & 1.40 & 1.70 & 2.13 & 2.11 & 2.02 & 2.14 & 2.31 & 2.23 & 2.76 & 2.56 & 2.60 \\
\hline \multirow{4}{*}{$\begin{array}{l}\text { Withers height } \\
(\mathrm{cm})\end{array}$} & CFG & 51.7 & 53.9 & 58.6 & 62.5 & 65.7 & 67.6 & 69.7 & 71.6 & 74.2 & 76.1 & 76.8 \\
\hline & AMFG & 51.8 & 54.4 & 58.3 & 63.5 & 66.6 & 69.0 & 71.2 & 72.5 & 75.4 & 76.5 & 78.1 \\
\hline & TMFG & 52.3 & 54.9 & 59.1 & 62.6 & 64.9 & 66.6 & 70.1 & 71.8 & 73.5 & 75.4 & 76.8 \\
\hline & SEM & 1.35 & 1.34 & 1.66 & 1.31 & 1.34 & 1.37 & 1.17 & 1.17 & 1.11 & 0.87 & 0.97 \\
\hline \multirow{4}{*}{$\begin{array}{l}\text { Body length } \\
(\mathrm{cm})\end{array}$} & CFG & 51.0 & 54.8 & 58.3 & 61.4 & 64.7 & 70.6 & 71.9 & 74.6 & 77.4 & 80.3 & 83.1 \\
\hline & AMFG & 50.5 & 55.1 & 60.4 & 64.5 & 67.1 & 71.1 & 73.5 & 76.6 & 79.2 & 81.5 & 84.8 \\
\hline & TMFG & 50.9 & 54.6 & 57.9 & 60.9 & 63.3 & 68.0 & 70.6 & 73.4 & 78.2 & 78.6 & 80.6 \\
\hline & SEM & 1.77 & 1.85 & 1.79 & 1.84 & 1.96 & 1.89 & 1.97 & 2.09 & 1.46 & 1.37 & 1.42 \\
\hline \multirow{4}{*}{$\begin{array}{l}\text { Hip height } \\
(\mathrm{cm})\end{array}$} & CFG & 52.3 & 55.1 & 58.9 & 62.8 & 65.4 & 67.4 & 70.5 & 72.1 & 74.2 & 75.8 & 77.0 \\
\hline & AMFG & 52.0 & 55.1 & 58.9 & 64.2 & 67.5 & 67.8 & 70.8 & 72.3 & 75.1 & 76.5 & 78.1 \\
\hline & TMFG & 52.4 & 55.1 & 59.8 & 62.9 & 65.3 & 66.4 & 70.9 & 73.2 & 74.7 & 75.8 & 77.5 \\
\hline & SEM & 1.30 & 1.22 & 1.36 & 1.38 & 1.41 & 1.43 & 0.98 & 0.92 & 1.15 & 1.11 & 1.04 \\
\hline \multirow{4}{*}{$\begin{array}{l}\text { Chest depth } \\
(\mathrm{cm})\end{array}$} & CFG & 19.1 & 20.6 & 22.7 & 24.2 & 25.4 & 26.6 & 28.3 & 30.1 & 31.7 & 32.7 & 33.3 \\
\hline & AMFG & 19.4 & 20.6 & 22.5 & 24.6 & 26.2 & 27.7 & 29.2 & 31.2 & 31.9 & 32.4 & 33.7 \\
\hline & TMFG & 19.4 & 21.1 & 22.3 & 24.7 & 25.5 & 26.9 & 28.2 & 29.4 & 30.6 & 32.7 & 33.6 \\
\hline & SEM & 0.56 & 0.55 & 0.62 & 0.57 & 0.52 & 0.64 & 0.57 & 0.81 & 0.58 & 0.65 & 0.53 \\
\hline \multirow{4}{*}{$\begin{array}{l}\text { Chest width } \\
(\mathrm{cm})\end{array}$} & CFG & 10.7 & 11.9 & 12.9 & 13.9 & 14.4 & 15.8 & 16.9 & 17.9 & 18.8 & 20.3 & 21.5 \\
\hline & AMFG & 10.8 & 11.8 & 13.6 & 14.3 & 15.6 & 16.8 & 17.3 & 18.4 & 19.2 & 20.1 & 21.0 \\
\hline & TMFG & 11.2 & 12.2 & 13.2 & 14.1 & 15.2 & 16.2 & 16.5 & 17.6 & 19.3 & 21.2 & 22.1 \\
\hline & SEM & 0.66 & 0.64 & 0.53 & 0.66 & 0.51 & 0.64 & 0.67 & 0.64 & 0.68 & 0.66 & 0.65 \\
\hline \multirow{4}{*}{$\begin{array}{l}\text { Chest girth } \\
(\mathrm{cm})\end{array}$} & CFG & 50.6 & 54.4 & 59.1 & 64.6 & 68.3 & 71.2 & 74.3 & 76.9 & 80.9 & 83.9 & 84.7 \\
\hline & AMFG & 51.4 & 54.1 & 59.4 & 65.2 & 69.0 & 73.0 & 75.6 & 77.9 & 82.3 & 83.2 & 85.6 \\
\hline & TMFG & 51.4 & 55.7 & 59.1 & 64.2 & 68.5 & 70.9 & 74.1 & 76.7 & 81.3 & 83.0 & 84.3 \\
\hline & SEM & 1.57 & 1.52 & 1.72 & 1.63 & 1.35 & 1.36 & 1.37 & 1.51 & 1.84 & 1.43 & 1.34 \\
\hline \multirow{4}{*}{$\begin{array}{l}\text { Hip width } \\
(\mathrm{cm})\end{array}$} & CFG & 9.3 & 10.1 & 10.9 & 11.7 & 12.2 & 12.7 & 13.3 & 14.0 & 14.6 & 15.3 & 16.7 \\
\hline & AMFG & 8.8 & 9.5 & 10.8 & 11.6 & 12.1 & 12.9 & 13.7 & 14.5 & 15.0 & 15.5 & 16.1 \\
\hline & TMFG & 9.3 & 9.8 & 10.6 & 11.5 & 12.3 & 12.7 & 13.2 & 14.0 & 14.5 & 15.6 & 16.2 \\
\hline & SEM & 0.45 & 0.43 & 0.51 & 0.41 & 0.39 & 0.44 & 0.48 & 0.46 & 0.44 & 0.49 & 0.51 \\
\hline
\end{tabular}

Values are mean of six animals $(n=6)$

${ }^{1}$ Control feed group. ${ }^{2}$ Awamori-pressed lees mixed feed group. ${ }^{3}$ Tofu lees mixed feed group. ${ }^{4}$ Standard error of the mean.

No significant differences were observed among the three kinds of feeds $(\mathrm{p}>0.05)$.

tended to be greater than those in the CFG. While the cumulative increases in withers height, body length and hip height in the TMFG were virtually the same as the CFG. The cumulative increases in body weight, chest depth, chest width, chest girth and hip width in the AMFG and TMFG were similar to the $\mathrm{CFG}$.

Table 8 shows the growth percentage of body parameters based on the measurements taken throughout the experiment. In the AMFG and TMFG, eighty percent of the withers height, hip height, body length and chest girth recorded at the conclusion of the experiment (13 mo old) were attained by the time the animals had reached 6 to 7 mo old. Eighty percent of the body length, chest depth, width, girth, and hip width measured at 13 mo old were attained by the time they were 8 to 9 mo old. Eighty percent of the body weight measurements recorded at 13 mo old was attained by the time they were 10 to 11 mo old. These are similar to the CFG.

\section{Blood composition analysis and physical observation}

Table 9 shows the blood parameters on the animals in the CFG, AMFG and TMFG. The hematocrit in the AMFG was virtually the same as the CFG while the values in the TMFG were tended to be higher than the CFG. The plasma concentrations of glucose, albumin, $\mathrm{Na}, \mathrm{K}$ and $\mathrm{Cl}$ in the AMFG and TMFG were virtually the same as those in the CFG. The plasma GOT and GPT concentration in the TMFG were virtually the same as those in the CFG while the values in the AMFG tended to be lower than the CFG. Plasma concentration of total cholesterol, triglyceride, HDL cholesterol, LDL cholesterol and non-esterified free fatty acid in the AMFG and TMFG were not significantly 
Table 7. Effect of feeding Awamori-pressed lees mixed feed (AMF) and Tofu lees mixed feed (TMF) on cumulative growth of male goats

\begin{tabular}{lcccc}
\hline Parameter & CFG $^{1}$ & AMFG $^{2}$ & TMFG $^{3}$ & SEM $^{4}$ \\
\hline Body weight (kg/10 month) & 39.2 & 39.5 & 39.0 & 2.46 \\
Withers height (cm/10 month) & 25.1 & 26.4 & 24.5 & 1.64 \\
Body length (cm/10 month) & 32.1 & 34.3 & 29.7 & 1.88 \\
Hip height (cm/10 month) & 24.8 & 26.1 & 25.3 & 1.71 \\
Chest depth (cm/10 month) & 14.2 & 14.2 & 14.2 & 0.60 \\
Chest width (cm/10 month) & 10.8 & 10.2 & 32.9 & 0.65 \\
Chest girth (cm/10 month) & 34.1 & 34.2 & 6.8 & 1.57 \\
Hip width (cm/10 month) & 7.3 & 7.3 & & 0.37 \\
\hline
\end{tabular}

Values are mean of six animals $(\mathrm{n}=6)$.

${ }^{1}$ Control feed group. ${ }^{2}$ Awamori-pressed lees mixed feed group. ${ }^{3}$ Tofu lees mixed feed group. ${ }^{4}$ Standard error of the mean.

Means of AMFG and TMFG in the same row are not significantly different from CFG $(\mathrm{p}>0.05)$.

Table 8. The growth percentage of body parameters based on the measurements taken throughout the experiment

\begin{tabular}{|c|c|c|c|c|c|c|c|c|c|c|c|c|}
\hline \multirow{2}{*}{ Parameter } & \multirow{2}{*}{ Feed } & \multicolumn{11}{|c|}{ Age in month } \\
\hline & & 3 & 4 & 5 & 6 & 7 & 8 & 9 & 10 & 11 & 12 & 13 \\
\hline \multirow{4}{*}{$\begin{array}{l}\text { Body weight } \\
(\%)\end{array}$} & $\mathrm{CFG}^{1}$ & 25.4 & 33.0 & 40.8 & 49.1 & 54.7 & 60.7 & 69.4 & 74.7 & 88.2 & 94.4 & 100.0 \\
\hline & $\mathrm{AMFG}^{2}$ & 25.3 & 31.5 & 40.7 & 50.4 & 57.5 & 64.5 & 71.6 & 79.4 & 91.3 & 95.0 & 100.0 \\
\hline & $\mathrm{TMFG}^{3}$ & 25.4 & 31.9 & 39.6 & 49.8 & 54.8 & 59.9 & 65.7 & 75.8 & 88.4 & 95.5 & 100.0 \\
\hline & $\mathrm{SEM}^{4}$ & 2.43 & 2.76 & 2.90 & 2.66 & 2.36 & 2.13 & 2.09 & 1.83 & 2.01 & 1.56 & - \\
\hline \multirow{4}{*}{$\begin{array}{l}\text { Withers height } \\
(\%)\end{array}$} & CFG & 67.4 & 70.3 & 76.3 & 81.4 & 85.5 & 88.1 & 90.8 & 93.3 & 96.7 & 99.1 & 100.0 \\
\hline & AMFG & 66.3 & 69.6 & 74.5 & 81.3 & 85.2 & 88.3 & 91.1 & 92.8 & 96.6 & 98.0 & 100.0 \\
\hline & TMFG & 68.2 & 71.5 & 77.1 & 81.5 & 84.5 & 86.7 & 91.3 & 93.5 & 95.7 & 98.2 & 100.0 \\
\hline & SEM & 1.90 & 1.67 & 2.07 & 1.57 & 1.25 & 1.38 & 0.93 & 1.19 & 1.14 & 0.62 & - \\
\hline \multirow{4}{*}{$\begin{array}{l}\text { Body length } \\
(\%)\end{array}$} & $\mathrm{CFG}$ & 61.4 & 65.9 & 70.1 & 73.8 & 77.7 & 84.9 & 86.3 & 89.5 & 93.0 & 96.6 & 100.0 \\
\hline & AMFG & 59.6 & 65.0 & 71.2 & 76.1 & 79.2 & 83.8 & 86.7 & 90.4 & 93.4 & 96.1 & 100.0 \\
\hline & TMFG & 63.3 & 67.8 & 71.8 & 75.5 & 78.4 & 84.4 & 87.6 & 91.0 & 97.1 & 97.5 & 100.0 \\
\hline & SEM & 2.01 & 2.04 & 1.60 & 1.44 & 1.39 & 1.41 & 1.26 & 1.41 & 0.79 & 0.79 & - \\
\hline \multirow{4}{*}{$\begin{array}{l}\text { Hip height } \\
(\%)\end{array}$} & CFG & 68.0 & 71.7 & 76.6 & 81.6 & 85.0 & 87.4 & 91.6 & 93.7 & 96.3 & 98.3 & 100.0 \\
\hline & AMFG & 66.7 & 70.6 & 75.5 & 82.2 & 86.5 & 86.9 & 90.7 & 92.7 & 96.2 & 98.1 & 100.0 \\
\hline & TMFG & 67.6 & 71.2 & 77.2 & 81.2 & 84.4 & 85.7 & 91.5 & 94.5 & 96.5 & 97.9 & 100.0 \\
\hline & SEM & 1.94 & 1.82 & 1.79 & 1.75 & 1.54 & 1.33 & 0.86 & 0.83 & 0.74 & 0.58 & - \\
\hline \multirow{4}{*}{$\begin{array}{l}\text { Chest depth } \\
\text { (\%) }\end{array}$} & CFG & 57.5 & 61.8 & 68.1 & 72.7 & 76.3 & 79.7 & 84.9 & 90.4 & 95.0 & 98.2 & 100.0 \\
\hline & AMFG & 57.7 & 61.2 & 66.9 & 73.1 & 77.8 & 82.4 & 86.6 & 92.6 & 94.7 & 96.2 & 100.0 \\
\hline & TMFG & 57.8 & 62.8 & 66.6 & 73.6 & 76.1 & 80.3 & 83.9 & 87.7 & 91.2 & 97.5 & 100.0 \\
\hline & SEM & 1.57 & 1.44 & 1.37 & 1.14 & 1.13 & 1.41 & 1.34 & 1.69 & 1.41 & 1.12 & - \\
\hline \multirow{4}{*}{$\begin{array}{l}\text { Chest width } \\
(\%)\end{array}$} & $\mathrm{CFG}$ & 49.9 & 55.5 & 60.4 & 64.7 & 67.2 & 73.7 & 78.9 & 83.5 & 87.7 & 94.8 & 100.0 \\
\hline & AMFG & 51.1 & 56.1 & 64.8 & 68.2 & 74.3 & 79.6 & 82.1 & 87.9 & 91.5 & 95.4 & 100.0 \\
\hline & TMFG & 50.4 & 55.2 & 59.9 & 63.5 & 68.8 & 73.0 & 74.6 & 79.4 & 87.2 & 95.8 & 100.0 \\
\hline & SEM & 2.67 & 2.88 & 2.19 & 2.55 & 2.08 & 2.06 & 2.49 & 2.30 & 2.14 & 1.44 & - \\
\hline \multirow{4}{*}{$\begin{array}{l}\text { Chest girth } \\
(\%)\end{array}$} & CFG & 59.7 & 64.3 & 69.8 & 76.2 & 80.6 & 84.1 & 87.8 & 90.8 & 95.5 & 99.0 & 100.0 \\
\hline & AMFG & 60.0 & 63.1 & 69.3 & 76.2 & 80.5 & 85.3 & 88.2 & 91.0 & 96.2 & 97.3 & 100.0 \\
\hline & TMFG & 61.0 & 66.0 & 70.1 & 76.2 & 81.4 & 84.1 & 87.9 & 90.9 & 96.3 & 98.4 & 100.0 \\
\hline & SEM & 1.68 & 1.55 & 1.54 & 1.49 & 1.36 & 1.10 & 0.95 & 0.97 & 1.20 & 0.67 & - \\
\hline \multirow{4}{*}{$\begin{array}{l}\text { Hip width } \\
(\%)\end{array}$} & CFG & 55.9 & 60.8 & 65.8 & 70.6 & 73.3 & 76.1 & 79.9 & 84.3 & 88.0 & 91.9 & 100.0 \\
\hline & AMFG & 54.6 & 59.1 & 66.6 & 72.2 & 75.0 & 80.0 & 85.0 & 89.9 & 93.4 & 96.5 & 100.0 \\
\hline & TMFG & 57.8 & 61.0 & 65.9 & 71.3 & 76.4 & 79.1 & 82.0 & 86.6 & 89.9 & 96.8 & 100.0 \\
\hline & SEM & 1.99 & 1.94 & 2.44 & 1.83 & 1.91 & 1.97 & 2.31 & 2.21 & 1.95 & 1.34 & - \\
\hline
\end{tabular}

Values are mean of six animals $(n=6)$.

Values were calculated by the data measured in each month divided by the data measured in 13 month.

${ }^{1}$ Control feed group. ${ }^{2}$ Awamori-pressed lees mixed feed group. ${ }^{3}$ Tofu lees mixed feed group. ${ }^{4}$ Standard error of the mean.

No significant differences were observed among the three kinds of feeds $(p>0.05)$. 
Table 9. Effect of feeding Awamori-pressed lees mixed feed (AMF) and Tofu lees mixed feed (TMF) on blood parameters in male goats

\begin{tabular}{|c|c|c|c|c|}
\hline Plasma component & $\mathrm{CFG}^{1}$ & $\mathrm{AMFG}^{2}$ & $\mathrm{TMFG}^{3}$ & $\mathrm{SEM}^{4}$ \\
\hline Hematocrit (\%) & 33.8 & 33.5 & 36.2 & 0.80 \\
\hline Blood Hemoglobin (g/dL) & 10.3 & 10.7 & 10.7 & 0.40 \\
\hline $\begin{array}{l}\text { Plasma osmolality } \\
(\mathrm{mOsm} / \mathrm{L})\end{array}$ & 299.2 & 299.5 & 299.7 & 1.38 \\
\hline Plasma total protein $(\mathrm{g} / \mathrm{dL})$ & 6.6 & 6.7 & 6.5 & 0.10 \\
\hline Plasma glucose $(\mathrm{mg} / \mathrm{dL})$ & 69.5 & 72.0 & 67.8 & 1.93 \\
\hline Plasma albumin (g/dL) & 3.5 & 3.6 & 3.3 & 0.09 \\
\hline Plasma $\mathrm{Na}(\mathrm{mmol} / \mathrm{L})$ & 141.7 & 140.8 & 139.7 & 0.88 \\
\hline Plasma K (mmol/L) & 5.1 & 5.1 & 5.1 & 0.14 \\
\hline Plasma Cl (mmol/L) & 101.3 & 100.3 & 101.2 & 0.77 \\
\hline Plasma GOT (IU/L) & 60.3 & 51.2 & 55.8 & 3.45 \\
\hline Plasma GPT (IU/L) & 19.8 & 14.8 & 19.7 & 1.78 \\
\hline $\begin{array}{l}\text { Plasma total cholesterol } \\
(\mathrm{mg} / \mathrm{dL})\end{array}$ & 57.1 & 65.6 & 65.0 & 5.87 \\
\hline $\begin{array}{l}\text { Plasma triglyceride } \\
(\mathrm{mg} / \mathrm{dL})\end{array}$ & 32.3 & $17.9^{*}$ & 38.2 & 3.67 \\
\hline $\begin{array}{l}\text { Plasma HDL cholesterol } \\
(\mathrm{mg} / \mathrm{dL})\end{array}$ & 26.0 & 30.8 & 27.8 & 3.19 \\
\hline $\begin{array}{l}\text { Plasma LDL cholesterol } \\
(\mathrm{mg} / \mathrm{dL})\end{array}$ & 24.6 & 31.2 & 29.5 & 6.03 \\
\hline $\begin{array}{l}\text { Plasma free fatty acid } \\
(\mu \mathrm{Eq} / \mathrm{L})\end{array}$ & 127.3 & 134.9 & 75.9 & 26.06 \\
\hline $\begin{array}{l}\text { Plasma phospholipids } \\
(\mathrm{mg} / \mathrm{dL})\end{array}$ & 59.7 & 55.2 & $107.8^{*}$ & 10.47 \\
\hline \multicolumn{5}{|c|}{$\begin{array}{l}\text { Values are mean of six animals }(n=6) \text {. } \\
{ }^{1} \text { Control feed group. }{ }^{2} \text { Awamori-pressed lees mixed feed group. } \\
{ }^{3} \text { Tofu lees mixed feed group. }{ }^{4} \text { Standard error of the mean. } \\
* \text { Means of AMFG and TMFG in the same row are significantly different } \\
\text { from CFG }(\mathrm{p}<0.05) .\end{array}$} \\
\hline
\end{tabular}

different from the CFG. Plasma phospholipids concentration in the TMFG was significantly higher $(\mathrm{p}<0.05)$ than the CFG, while that in the AMFG was similar to the CFG.
The coats of the animals in the AMFG and TMFG were observed to be shinier than the CFG animals. This was particularly apparent in the AMFG animals.

\section{The carcass characteristics}

Carcass characteristics are shown in Table 10. There was no significant difference in the body weight before slaughter of the animals in all three treatments (AMFG, TMFG, CFG). While the weight of the dressed carcass and dressing percentage of animals in the AMFG were not significantly different from the CFG, the weight of dressed carcasses from the TMFG tended to be slightly smaller than the CFG. There was no significant difference in weight of the Loin, Chuck, Brisket, Plate and Flank, and Round areas of carcasses between the AMFG and CFG. In contrast, the weight of the Chuck area in the TMFG was lighter than the CFG $(p<0.05)$ and the Loin, Brisket, Plate and Flank, and Round areas tended to be lighter than the CFG. The rib eye area in AMFG tended to be larger than the CFG while the same area in TMFG tended to be smaller than the CFG.

\section{Physical characteristics of the loin}

The physical characteristics on the loin are shown in Table 11. While cooking loss in the TMFG was the same as the CFG, that in the AMFG was significantly higher than the CFG $(p<0.05)$. Tenderness of the meat from the TMFG was the same as the CFG while that in the AMFG tended to be larger. In contrast, while the compressed meat juice ratio in the AMFG tended to be higher than the CFG, the ratio of the TMFG was significantly higher $(\mathrm{p}<0.05)$ than the CFG. The water holding capacity of the AMFG was the same as the CFG and tended to be higher in the TMFG.

\section{Fatty acids composition in the loin}

The fatty acid composition of the loin is shown in Table 12. The melting point of fat in the loin in the AMFG and

Table 10. Effect of feeding Awamori-pressed lees mixed feed (AMF) and Tofu lees mixed feed (TMF) on meat production in male goats

\begin{tabular}{|c|c|c|c|c|}
\hline Parameter & $\mathrm{CFG}^{1}$ & $\mathrm{AMFG}^{2}$ & $\mathrm{TMFG}^{3}$ & $\mathrm{SEM}^{4}$ \\
\hline Body weight (kg) & 52.4 & 52.8 & 52.3 & 2.60 \\
\hline Dressing carcass $(\mathrm{kg})^{5}$ & 25.4 & 25.7 & 23.5 & 0.69 \\
\hline Dressing percentage $(\%)^{6}$ & 48.5 & 48.7 & 44.9 & 1.21 \\
\hline Total weight of meat $(\mathrm{kg})^{7}$ & $15.6^{\mathrm{a}}$ & $14.8^{\mathrm{ab}}$ & $13.7^{\mathrm{b}}$ & 0.54 \\
\hline Loin $(g)^{7}$ & 915 & 951 & 820 & 39.07 \\
\hline Chuck $(g)^{7}$ & $2,245^{\mathrm{a}}$ & $1,985^{\mathrm{a}}$ & $1,710^{\mathrm{b}}$ & 154.46 \\
\hline Brisket $(\mathrm{g})^{7}$ & 3,410 & 3,125 & 2,930 & 139.37 \\
\hline Plate and Flank $(\mathrm{g})^{7}$ & 3,615 & 3,335 & 3,180 & 127.29 \\
\hline Round $(g)^{7}$ & 5,375 & 5,405 & 5,065 & 108.68 \\
\hline Rib eye area $\left(\mathrm{cm}^{2}\right)$ & 15.2 & 16.8 & 12.4 & 1.29 \\
\hline
\end{tabular}

Values are mean of six animals $(n=6)$.

${ }^{1}$ Control feed group. ${ }^{2}$ Awamori-pressed lees mixed feed group. ${ }^{3}$ Tofu lees mixed feed group.

${ }^{4}$ Standard error of the mean. ${ }^{5}$ Combined weight of left and right carcasses after removed head and internal organs.

${ }^{6}$ Weight of dressing carcass $(\mathrm{kg}) /$ body weight $(\mathrm{kg}) \times 100 .{ }^{7}$ Weight without bone.

${ }^{\mathrm{a}, \mathrm{b}}$ Means in the same row bearing different superscripts are significantly different $(\mathrm{p}<0.05)$. 
Table 11. Effect of feeding Awamori-pressed lees mixed feed (AMF) and Tofu lees mixed feed (TMF) on physical characteristics of loin in male goats

\begin{tabular}{lllll}
\hline Parameter & $\mathrm{CFG}^{1}$ & AMFG $^{2}$ & TMFG $^{3}$ & SEM $^{4}$ \\
\hline Cooking loss (\%) & $30.3^{\mathrm{a}}$ & $32.2^{\mathrm{b}}$ & $31.0^{\mathrm{ab}}$ & 0.55 \\
Tenderness (kgf/cm $\left.{ }^{2}\right)$ & 70.6 & 81.0 & 71.8 & 3.28 \\
Water holding capacity & 78.6 & 79.1 & 82.7 & 1.29 \\
Compressed meat & $34.3^{\mathrm{a}}$ & $36.2^{\mathrm{ab}}$ & $38.1^{\mathrm{b}}$ & 1.10 \\
juice ratio (\%) & & & \\
Values are mean of six animals (n $=6$ ). \\
${ }^{1}$ Control feed group. ${ }^{2}$ Awamori-pressed lees mixed feed group. \\
${ }^{3}$ Tofu lees mixed feed group. ${ }^{4}$ Standard error of the mean. \\
a,b Means in the same row bearing different superscripts are significantly \\
different (p<0.05).
\end{tabular}

TMFG tended to be lower than the CFG. Compared with the $\mathrm{CFG}$, there was no significant difference in the total lipid content in the loin of the AMFG and TMFG. Compared to the CFG, the ratio of saturated fatty acids in the AMFG tended to be lower. There was no difference in that between the TMFG and CFG. In contrast, compared to the CFG, the ratio of unsaturated fatty acids tended to be higher for the AFMG and unchanged in the TMFG. Myristic acid (C14:0) ratio in the AMFG was significantly higher $(\mathrm{p}<0.05)$ than the CFG. The margaric acid (C17:0) and arachidic acid (C20:0) ratios in the AMFG were significantly lower $(p<0.05)$ than those in the CFG. There were no differences in the ratios of other saturated fatty acids between the AMFG and CFG. On the other hand, in the TMFG, ratios of palmitic acid (C16:0) tended to be higher than the CFG while all other saturated fatty acids were the same as the CFG. The ratios of miristoleic acid (14:1), palmitoleic acid (C16:1), heptadecenoic acid (C17:1), oleic acid (C18:1) and cis-vaccenic acid (C18:1) in the AMFG tended to be higher than those in the CFG. The ratios of all other unsaturated fatty acids in the AMFG were the same as the CFG. The ratio of linoleic acid (C18:2) in the TMFG was significantly higher than the CFG. The ratios of all other unsaturated fatty acids in the TMFG were the same as the CFG.

\section{Free amino acids concentration in the loin}

Free amino acids concentration in the loin is shown in Table 13. Free amino acids concentration in the loin of the AMFG tended to be lower than that in the CFG. There was no difference in concentrations observed between the TMFG and CFG. Virtually all the essential amino acid concentrations in the AMFG were significantly lower $(\mathrm{p}<0.05)$ than the CFG. There was no significant difference between the TMFG and CFG. Of the non essential amino acid concentrations, proline and asparagines in the AMFG and glutamic acid in the TMFG were significantly lower $(\mathrm{p}<0.05)$ than the CFG. In contrast, alanine and glycine in the TMFG tended to be higher than the CFG. All other non essential amino acid concentrations in the AMFG and
Table 12. Effect of feeding Awamori-pressed lees mixed feed (AMF) and Tofu lees mixed feed (TMF) on fatty acid composition of loin in male goats

\begin{tabular}{lcccc}
\hline Parameter & CFG $^{1}$ & AMFG $^{2}$ & TMFG $^{3}$ & SEM $^{4}$ \\
\hline Melting point of fat $\left({ }^{\circ} \mathrm{C}\right)^{5}$ & 43.8 & 34.8 & 37.8 & 2.65 \\
Total lipid content $(\mathrm{g} / 100 \mathrm{~g})$ & $3.0^{\mathrm{ab}}$ & $3.4^{\mathrm{a}}$ & $2.9^{\mathrm{b}}$ & 0.15 \\
Saturated fatty acids $(\%)$ & 47.8 & 39.7 & 50.8 & 3.32 \\
C10:0 & $0.1^{\mathrm{a}}$ & $0.0^{\mathrm{b}}$ & $0.1^{\mathrm{a}}$ & 0.03 \\
C12:0 & $0.0^{\mathrm{a}}$ & $0.1^{\mathrm{b}}$ & $0.0^{\mathrm{a}}$ & 0.03 \\
C14:0 & $2.7^{\mathrm{a}}$ & $3.0^{\mathrm{b}}$ & $2.8^{\mathrm{ab}}$ & 0.09 \\
C15:0 & $0.8^{\mathrm{ab}}$ & $0.9^{\mathrm{a}}$ & $0.7^{\mathrm{b}}$ & 0.06 \\
C16:0 & 22.1 & 21.8 & 24.3 & 0.79 \\
C17:0 & $1.6^{\mathrm{a}}$ & $1.3^{\mathrm{b}}$ & $1.5^{\mathrm{ab}}$ & 0.09 \\
C18:0 & 20.2 & 12.4 & 21.1 & 2.76 \\
C20:0 & $0.3^{\mathrm{a}}$ & $0.2^{\mathrm{b}}$ & $0.3^{\mathrm{a}}$ & 0.03 \\
Unsaturated fatty acids $(\%)$ & 46.8 & 53.6 & 45.2 & 2.58 \\
C14:1 & $0.5^{\mathrm{ab}}$ & $1.1^{\mathrm{a}}$ & $0.2^{\mathrm{b}}$ & 0.26 \\
C16:1 & 2.2 & 4.1 & 2.0 & 0.67 \\
C17:1 & $1.3^{\mathrm{ab}}$ & $1.9^{\mathrm{a}}$ & $0.9^{\mathrm{b}}$ & 0.29 \\
C18:1 & 37.8 & 41.3 & 36.8 & 1.36 \\
C18:1 cis-11 & 2.1 & 2.4 & 2.1 & 0.10 \\
C18:2 & $2.2^{\mathrm{a}}$ & $2.2^{\mathrm{a}}$ & $2.3^{\mathrm{b}}$ & 0.03 \\
C18:3 & $0.4^{\mathrm{ab}}$ & $0.3^{\mathrm{a}}$ & $0.5^{\mathrm{b}}$ & 0.06 \\
C20:1 & $0.0^{\mathrm{a}}$ & $0.1^{\mathrm{b}}$ & $0.0^{\mathrm{a}}$ & 0.03 \\
C20:4 & 0.2 & 0.2 & 0.2 & 0.00 \\
C22:5 & $0.1^{\mathrm{ab}}$ & $0.0^{\mathrm{a}}$ & $0.2^{\mathrm{b}}$ & 0.06 \\
Not indentified $(\%)$ & $5.4^{\mathrm{ab}}$ & $6.7^{\mathrm{a}}$ & $4.0^{\mathrm{b}}$ & 0.78 \\
\hline Valus & & &
\end{tabular}

Values are mean of six animals $(n=6)$

${ }^{1}$ Control feed group. ${ }^{2}$ Awamori-pressed lees mixed feed group.

${ }^{3}$ Tofu lees mixed feed group. ${ }^{4}$ Standard error of the mean.

${ }^{5}$ Melting point of fat extracted from the loin.

${ }^{\mathrm{a}, \mathrm{b}}$ Means in the same row bearing different superscripts are significantly different $(\mathrm{p}<0.05)$.

TMFG were the same as the CFG. Of the functional amino acids, taurine concentration in the AMFG tended to be higher than the CFG. There was no observable difference in taurine between the TMFG and CFG. While concentration of carinosine in the AMFG tended to be a higher than the CFG, there was no difference between the TMFG and CFG. Anserine in the TMFG was significantly lower $(\mathrm{p}<0.05)$ and that in the AMFG tended to be lower than the CFG.

\section{Size of various organs}

The size of various organs is shown in Table 14. The weight of liver, lungs and trachea, large and small intestine in the AMFG was significantly $(\mathrm{p}<0.05)$ lower than the CFG. There was no significant difference in the weight of other visceral organs between the AMFG and the CFG. The weight of the reticulum in the TMFG was significantly lower than the CFG $(\mathrm{p}<0.05)$. The weight of other visceral organs in the TMFG was not significantly different from the CFG. However, the length of the small intestine in the AMFG, and both the larger and small intestine in the TMFG 
Table 13. Effect of feeding Awamori-pressed lees mixed feed (AMF) and Tofu lees mixed feed (TMF) on free amino acids content of loin in male goats

\begin{tabular}{|c|c|c|c|c|}
\hline Parameter $(\mathrm{mg} / 100 \mathrm{~g} \mathrm{FM})$ & $\mathrm{CFG}^{1}$ & $\mathrm{AMFG}^{2}$ & $\mathrm{TMFG}^{3}$ & $\mathrm{SEM}^{4}$ \\
\hline Total free amino acid & $397.5^{\mathrm{a}}$ & $360.9^{\mathrm{b}}$ & $389.8^{\mathrm{ab}}$ & 11.14 \\
\hline Essential amino acids & 46.4 & 34.8 & 39.6 & 3.37 \\
\hline Threonine & $12.1^{\mathrm{a}}$ & $10.7^{\mathrm{b}}$ & $11.2^{\mathrm{ab}}$ & 0.41 \\
\hline Leucine & $7.4^{\mathrm{a}}$ & $5.4^{\mathrm{b}}$ & $6.2^{\mathrm{ab}}$ & 0.58 \\
\hline Lysine & $6.2^{\mathrm{a}}$ & $5.0^{\mathrm{b}}$ & $5.8^{\mathrm{ab}}$ & 0.35 \\
\hline Valine & $5.2^{\mathrm{a}}$ & $4.0^{\mathrm{b}}$ & $4.7^{\mathrm{ab}}$ & 0.35 \\
\hline Histidine & $5.0^{\mathrm{a}}$ & $2.7^{\mathrm{b}}$ & $3.6^{\mathrm{ab}}$ & 0.67 \\
\hline Phenylalanine & 4.6 & 3.2 & 3.5 & 0.43 \\
\hline Isoleucine & $3.3^{\mathrm{a}}$ & $2.3^{\mathrm{b}}$ & $2.7^{\mathrm{ab}}$ & 0.29 \\
\hline Methionine & $2.6^{\mathrm{a}}$ & $1.5^{\mathrm{b}}$ & $1.9^{\mathrm{ab}}$ & 0.32 \\
\hline Non-essential amino acids & 199.6 & 164.6 & 199.7 & 11.68 \\
\hline Glutamine & 107.7 & 90.1 & 107.0 & 5.75 \\
\hline Alanine & 32.6 & 27.9 & 35.5 & 2.21 \\
\hline Glycine & 19.4 & 12.7 & 23.0 & 3.02 \\
\hline Glutamic acid & $18.9^{\mathrm{a}}$ & $17.1^{\mathrm{ab}}$ & $14.4^{\mathrm{b}}$ & 1.31 \\
\hline Arginine & 8.9 & 7.6 & 8.7 & $0 . .40$ \\
\hline Serine & 4.9 & 3.7 & 5.0 & 0.42 \\
\hline Proline & $3.7^{\mathrm{a}}$ & $3.0^{\mathrm{b}}$ & $3.2^{\mathrm{ab}}$ & 0.21 \\
\hline Asparagine & $3.0^{\mathrm{a}}$ & $2.0^{\mathrm{b}}$ & $2.4^{\mathrm{ab}}$ & 0.29 \\
\hline Aspartic acid & 0.5 & 0.5 & 0.5 & 0.00 \\
\hline Cystine & 0.0 & 0.0 & 0.0 & 0.00 \\
\hline Tyrosine & 0.0 & 0.0 & 0.0 & 0.00 \\
\hline \multicolumn{5}{|l|}{ Functional amino acids } \\
\hline Taurine & 148.8 & 159.7 & 148.9 & 3.62 \\
\hline Ornithine & 2.7 & 1.8 & 1.6 & 0.35 \\
\hline \multicolumn{5}{|l|}{ Peptides } \\
\hline Carnosine & 176.4 & 242.2 & 160.5 & 25.01 \\
\hline Anserine & $161.2^{\mathrm{a}}$ & $140.9^{\mathrm{ab}}$ & $116.5^{\mathrm{b}}$ & 12.92 \\
\hline
\end{tabular}

Values are mean of six animals $(n=6)$.

${ }^{1}$ Control feed group. ${ }^{2}$ Awamori-pressed lees mixed feed group. ${ }^{3}$ Tofu lees mixed feed group. ${ }^{4}$ Standard error of the mean.

${ }^{\mathrm{a}, \mathrm{b}}$ Means in the same row bearing different superscripts are significantly different $(\mathrm{p}<0.05)$.

tended to be longer than the CFG.

\section{DISCUSSION}

\section{Availability of food by-products for goats}

The ether extracts content of dried Awamori-pressed lees and dried Tofu lees (15.7\% and $14.3 \%$ respectively) was substantially higher than levels found in corn and soy bean meal (Table 1; NARO, 2010). Compared with corn and soy bean meal, the NFE content of both Awamoripressed lees and Tofu lees was lower. This is because, in Awamori-pressed lees, the rice starch has been used in the alcohol fermentation process, and in the case of Tofu lees, the majority of the soy bean protein is used in the production of Tofu. A large number of food by-products are nutritionally unbalanced. In order to use them as livestock feed, the nutritional deficiency must be understood and the food by-product combined with other feed ingredients to produce a nutritionally balanced final product (Saeki, 2007). Although both by-products are nutritionally unbalanced, they have a high content of nutritional elements such as protein and lipids, and bioactive substances such as citric acid and isoflavones (Table 1; Inada et al., 2003; Genovese et al., 2006; Takaya et al., 2007). In this study, Awamoripressed lees and Tofu lees were added to flaked corn, soy bean meal, and wheat bran to improve the nutritional balance and ensure that the TDN and DCP levels of the feed were virtually the same as control feed (Tables 2 and 3).

\section{Experimental design}

The control feed (CF) was made mainly using corn, wheat bran and soybean meal. On the other hand, in the Awamori-pressed lees mixed feed (AMF) and Tofu lees mixed feed (TMF), these crops were replaced partly by the Awamori-pressed lees or Tofu lees. The same amounts of TDN and DCP were fed different groups of goats (CFG, 
Table 14. Effect of feeding Awamori-pressed lees mixed feed (AMF) and Tofu lees mixed feed (TMF) on various organs in male goats

\begin{tabular}{|c|c|c|c|c|}
\hline Parameter & $\mathrm{CFG}^{1}$ & $\mathrm{AMFG}^{2}$ & TMFG $^{3}$ & $\mathrm{SEM}^{4}$ \\
\hline \multicolumn{5}{|l|}{ Weight (g) } \\
\hline Liver & $720^{\mathrm{a}}$ & $621^{\mathrm{b}}$ & $675^{\mathrm{a}}$ & 28.62 \\
\hline Kidneys & 130 & 130 & 130 & 0.00 \\
\hline Heart & 223 & 172 & 215 & 15.84 \\
\hline Lungs and trachea & $582^{\mathrm{a}}$ & $440^{\mathrm{b}}$ & $513^{\mathrm{a}}$ & 41.00 \\
\hline Spleen & 75 & 63 & 60 & 4.58 \\
\hline Rumen & 890 & 778 & 923 & 43.88 \\
\hline Reticulum & $162^{\mathrm{a}}$ & $147^{\mathrm{a}}$ & $135^{\mathrm{b}}$ & 7.81 \\
\hline Omasum & 150 & 120 & 132 & 8.72 \\
\hline Abomasum & 265 & 155 & 190 & 32.45 \\
\hline Large and small intestine & $2,600^{\mathrm{a}}$ & $2,300^{\mathrm{b}}$ & $2,380^{\mathrm{ab}}$ & 89.69 \\
\hline \multicolumn{5}{|l|}{ Length $(\mathrm{cm})$} \\
\hline Large intestine & 680 & 650 & 725 & 21.79 \\
\hline Small intestine & 1,960 & 2,163 & 2,300 & 98.76 \\
\hline
\end{tabular}

Values are mean of six animals $(n=6)$.

${ }^{1}$ Control feed group. ${ }^{2}$ Awamori-pressed lees mixed feed group. ${ }^{3}$ Tofu lees mixed feed group. ${ }^{4}$ Standard error of the mean.

${ }^{\mathrm{a}, \mathrm{b}}$ Means in the same row bearing different superscripts are significantly different $(\mathrm{p}<0.05)$.

AMFG and TMFG), satisfied the NRC standards (2006), and produced a daily body weight gain of $100 \mathrm{~g} / \mathrm{d}$.

This study examined whether the goats in AMFG and TMFG grew in the same manner as the CFG, and whether loin meat with good quality could be produced. From these results, it was clarified whether or not Awamori-pressed lees or Tofu lees could be used as a feed ingredient for rearing of goats.

\section{Nutritive value of mixed feed on growing goats}

In this research, the experiment was designed in accordance to NRC standards in order to produce a $100 \mathrm{~g} / \mathrm{d}$ body weight increase. Between the ages of 3 and 13 mo, the growing goats in their respective groups were given mixed feed that contained either $20 \%$ Awamori-pressed lees or Tofu lees. Each group in the experiment was fed each mixed feed of approximately 2,090 gDM/d/6 head from 3 to 5 mo old. This was increased to approximately 2,610 g $\mathrm{DM} / \mathrm{d} / 6$ head from 6 to 13 mo old (Table 4). The mixed feed given to the animals in the morning and again in the afternoon in the AMFG and TMFG groups was consumed in its entirety within one hour of the start of feeding. From this, it was clarified that the feed contained 20\% Awamoripressed lees or Tofu lees was as palatable as the control feed.

TDN intake percentage from the mixed feed given to the animals in the CFG, AMFG, and TMFG between 3 and 13 mo of age was 72.9 to $42.5 \%$ (CFG), 73.4 to $43.1 \%$ (AMFG) and 73.2 to $42.8 \%$ (TMFG)(Table 5). DCP intake percentage from the mixed feed given to the animals in the CFG, AMFG, and TMFG between 3 and 13 mo of age was 61.3 to $26.7 \%$ (CFG), 61.9 to $27.2 \%$ (AMFG) and 61.5 to $26.9 \%$ (TMFG)(Table 5).
In order to ensure that growing goats receive the nutrients for growth, they have to take mixed feed including protein, vitamins, and minerals. The present results indicate that while the majority of the TDN and DCP consumed by the animals during the first half of their growth period in this experiment were obtained from the mixed feed, in the second half of their growth period TDN and DCP were obtained from both the mixed feed and roughage.

The daily body weight gain during the experiment was $126.3 \pm 8.18 \mathrm{~g} / \mathrm{d}$ (CFG), 127.3 $\pm 7.05 \mathrm{~g} / \mathrm{d}$ (AMFG) and $125.9 \pm 8.50 \mathrm{~g} / \mathrm{d}$ (TMFG)(Tables 6 and 7). These results indicate that each animal in the CFG, AMFG, and TMFG gained in excess of $100 \mathrm{~g} / \mathrm{d}$. Growth of animals is significantly affected by both genetics and feed intake (Hammond et al., 1971; Cheema et al., 1991; Bortone et al., 1994; Jia et al., 1995; Negesse et al., 2001). All of the animals used in this experiment were Saanen/Nubian crossbreeds (F1) and therefore their genetic characteristics were all similar. Among the animals in the groups in this experiment, none were observed to be noticeably stronger or weaker than the others in the group. While it is possible that some animals were prevented from consuming the same amount of feed as other animals in the group, all the animals in the experiment increased their body weight by $100 \mathrm{~g} / \mathrm{d}$. This suggests that necessary TDN and DCP amount were obtained from the mixed feed in amounts sufficient for the growth observed. The growth of the animals in the AMFG and TMFG was the same as the CFG.

The consumption of hay is restricted by factors including the development of ruminal capacity and salivary secretion (Sunagawa et al., 2007; Thang et al., 2012). In this experiment, the increase in hay intake in conjunction with the increase in age of the animals in the AMFG and TMFG 
was the same as the animals in the CFG. This indicated that the development of the digestive organs, including the rumen and salivary glands in the animals of the AMFG and TMFG was the same as the animals in the CFG.

Effect of AMF and TMF feeding on blood parameters in growing male goats

The blood parameters in the AMFG and TMFG were similar to the CFG. The blood parameters in this experiment were similar to the values obtained from a normal male goat (Dehghani et al., 2000; Nazifi et al., 2002; Solaiman et al., 2009; Eiselt et al., 2011). Concentration of phospholipids in the TMFG was significantly higher $(p<0.05)$ than the CFG. This may be due to high content of phospholipids in Tofu lees. The results indicate that feeding goats mixed feed containing $20 \%$ of Awamori-pressed lees or Tofu lees contributes towards maintaining normal body condition the same as feeding goats control feed containing no lees.

\section{Effects of Awamori-pressed lees and Tofu lees on meat production}

Body weights of the animals in the AMFG and TMFG treatments upon conclusion of the experiment were not significantly different from the CFG (Table 6). In contrast, the dressing carcass weight, dressing percentage, and total meat weight of the animals from the AMFG treatment were virtually equal to the CFG while those in the TMFG treatment tended to be smaller than the CFG (Table 10). These results indicate that while the skeletal and muscle tissue development of the animals in the AMFG was virtually the same as the CFG animals, the TMFG animals developed less muscle tissue than the CFG. The reason for this is thought to be the fact that the TMF feed contained a higher concentration of fat than the control feed (Table 3) and thus the TMFG animals had a higher amount of visceral and subcutaneous fat than the animals in the CFG.

The main components of meat are protein and fat. The meat is created from the nitrogen compounds and lipids in the feed. The lipids content of the AMF and TMF was high (6.0\% and $5.7 \%$ respectively, Table 3 ). High lipid content of the feed decreases the activity of ruminal micro-organisms, and also hydrogenation of unsaturated fatty acids (Hino and Nagatake, 1993). However, the results of this experiment indicate that hydrogenation of unsaturated fatty acids by ruminal micro-organisms still occurred. The linoleic acid (C18:2) content in fat of the Awamori-pressed lees and Tofu lees was $46.1 \%$ (Yamasaki et al., 2006) and 50.8\% (Ishiyaku Publishers, 2011) respectively. In the fat of loin in the AMFG and TMFG animals, linoleic acid percentage was approximately $2 \%$, and there was a higher percentage of palmitic acid (C16:0), stearic acid (C18:0) and oleic acid (C18:1). This indicates that the linoleic acid was subjected to hydrogenation by micro-organisms in the rumen. Therefore, it was clarified that the feed containing $20 \%$ Awamori-pressed lees or Tofu lees did not inhibit the activity of ruminal micro-organisms.

The loin meat of the AMFG and TMFG animals were still well balanced and contained high levels of both the essential and non-essential amino acids the same as the CFG animals (Table 13). The concentrations of taurine (anti-fatigue) (Silva et al., 2011), and carnosine (antioxidant) in the loin of the AMFG were higher than the CFG (Kalaz et al., 2012). The concentration of taurine and carnosine in the loin of the TMFG was the same as the CFG. In the loin fat of AMFG and TMFG animals, oleic acid percentages were $41.3 \%$ and $36.8 \%$ respectively. It has been reported that oleic acid has a moisturizing effect on the skin and serves prevent or improve hypertension (Zhang et al., 2010; Hoops et al., 2011). The compressed meat juice ratio from AMFG and TMFG animals was higher than the CFG animals (Table 12). This result indicates that meat produced by feed mixed with $20 \%$ Awamori-pressed lees or Tofu lees is juicier. These results indicate that loin meat produced from feed containing Awamori-pressed lees and Tofu lees is high in quality and contains an abundance of bio-active functional compounds. The consumption of this meat would contribute greatly to the promotion and maintenance of health in humans.

This experiment demonstrates that Awamori-pressed lees and Tofu lees can be used as feed ingredient for rearing male goats during growth periods. The results of this experiment suggest that through developing new types of feed ingredients, a significant contribution can be made in addressing the feed cost issues faced by farmers.

\section{ACKNOWLEDGEMENTS}

We thank Mr. Kazuki Katrori, Miss Mana Inagaki, Mr. Tomoyuki Namima, and Mr. Daisuke Nakama for their helpful assistance in experiments and recording the data. We thank Mr. Masahide Shinjo, the owner of Hagoromo Farm where this experiment was conducted. We also thank Mr. Glenn McIlvride for his English proof-reading on this manuscript. This research was conducted in part with funding from the 'Uruma Academic Research Fund'. The computation was mainly carried out using the computer facilities in Research Institute for Information Technology, Kyushu University.

\section{REFERENCES}

Bortone, E. J., J. L. Morrill, and J. S. Stevenson. 1994. Growth of heifers fed 100 or $115 \%$ of National Research Council requirements to 1 year of age and then changed to another treatment. J. Daily Sci. 77:270-277. 
Cheema, A. U., M. L. Galyean, J. S. Caton, and A. S. Freeman. 1991. Influence of protein levels and naloxone on intake, nitrogen metabolism and digestion kinetics in lambs fed oat hay or barley straw. Small Rumin. Res. 5:35-46.

Dehghani, S., S. Nazifi, and M. R. Barzegar. 2000. Evaluation of cellular and biochemical parameters of blood and peritoneal fluid following exploratory laparotomy in the goat. J. Vet. Med. A 47:143-148.

Eiselt, N., H. Wagner, and A. Wehrend. 2011. Haematologic parameters in goats. Ieraerztliche Praxis Ausgabe Grosstiere Nutztiere 39:49-55.

FAO. 2008. The Investment Imperative, paper from the FAO High Level Conference on World Food Security: The Challenges of Climate Change and Bioenergy. Food and Agriculture Organization, Rome.

Folch. J., M. Less, and G. H. S. Stanley. 1957. A simple method for the isolation and purification of total lipids from animal tissues. J. Biol. Chem. 226:497-509.

Fujitani, Y., S. Nobuhara, S. Ohtani, K. Nishimura, S. Mohri, and T. Ohishi. 2000. Effect of both full-fat rice bran and tofu cake diets on feed intake and weight grain in Holstein steers. Bulletin of Osaka Agriculture and Forestry Research Center 36:48-52.

Genovese, M. I., J. Davila, and F. M. Lajolo. 2006. Isoflavones in Processed Soybean Products from Ecuador. Braz. Arch. Biol. Technol. 49:853-859.

Godel, H., T. Graser, P. Földi, P. Pfaender, and P. Fürst. 1984. Measurement of free amino acids in human biological fluids by high-performance liquid chromatography. J. Chromatogr. 297:49-61.

Hammond, J., I. L. Mason, and T. J. Robinson. 1971. Hammond's farm animals. 4th Ed. St. Martin's Press. London. pp. 18-30.

Hino, T., and Y. Nagatake. 1993. The effect of grass lipids on fiber digestion by mixed rumen microorganisms in vitro. Anim. Sci. Techol. (Jpn.) 64:121-128.

Hoopes, M. I., M. G. Noro, M. L. Longo, and R. Faller. 2011. Bilayer structure and lipid dynamics in a model stratum corneum with oleic acid. J. Phys. Chem. B. 115:3164-3171.

Inada, S., T. Kola and Y. Isozaki. 2003. Composition and Digestive Characteristics of Steam Dried Tofu Cake for Feed of Cattle. The West Japan Journal of Animal Science 46:23-27.

Ishiyaku Publishers. 2011. Standard tables of food composition in Japan. Ishiyaku Publishers Inc., Tokyo Japan. pp. 270:324-325.

Jia, Z. H., T. Sahlu, J. M. Femandez, S. P. Hart, and T. H. Teh 1995. Effects of dietary protein level on performance of Angora and cashmere-producing Spanish goats. Small Rumin. Res. 16:113-119.

Kalaz, E. B., B. Evran, S. Develi-İş1, P. Vural, S. DoğruAbbasoğlu, and M. Uysal. 2012. Effect of carnosine on prooxidant-antioxidant balance in several tissues of rats exposed to chronic cold plus immobilization stress. J. Pharmacol. Sci. 120:98-104.

Lengemann, F. W., and N. N. Allen. 1955. The development of rumen function in the dairy calf: 1 . Some characteristics of the rumen contents of cattle of various ages. J. Dairy Sci. 38:651656.

Nagamine, I., K. Sunagawa, and T. Kishi. 2012. Use of Awamoripressed lees and Tofu lees as feed ingredients for growing female goats. Asian-Aust. J. Anim. Sci. 25:1701-1711.
NARO. 2010. Standard tables of feed composition in Japan (2009). National Agriculture and Food Research Organization, Tokyo, Japan. pp. 80-93.

Nazifi, S., H. R. Gheisari, and F. Shaker. 2002. Serum lipids and lipoproteins and their correlations with thyroid hormones in clinically healthy goats. Vet. Arh. 72:249-257.

Negesse, T., M. Rodehutscord, and E. Pfeffer. 2001. The effect of dietary crude protein level on intake, growth, protein retention and utilization of growing male Saanen kids. Small Rumin. Res. 39:243-251.

NRC. 2006. Nutrient requirements of small ruminants. National research council. The national academies. Washington, DC, USA. pp. 271-299.

Qureshi, G. A., L. Fohlin, and J. Bergström. 1984. Application of high-performance liquid chromatography to the determination of free amino acids in physiological fluids. J. Chromatogr. A. 297: 91-100.

Saeki, M. 2007. The characteristic and the utilization of Eco-feed for swine. Proceedings of Japanese Society for Animal Nutrition and Metabolism 51:15-20.

SAS. 1990. SAS/STAT user's guide: Volume 2, Version 6. 4th Ed. SAS Institute Inc., SAS Campus Drive, Cary, NC 27513.

Scott, B., M. Clements, C. Griffiths, and J. Ihrig. 2009. Biofuels impact on crop and food prices: Using an interactive spreadsheet. International Finance Discussion Papers 967:1-30.

Silva, L. A., P. C. L. Silveira, M. M. Ronsani, P. S. Souza, D. Scheffer, L. C. Vieira, M. Benetti, C. T. De Souza, and R. A. Pinho. 2011. Taurine supplementation decreases oxidative stress in skeletal muscle after eccentric exercise. Cell Biochem. Funct. 29:43-49.

Solaiman, S. G., N. K. Gurung, Q. McCrary, H. Goyal, and W. H. McElhenney. 2009. Feeding performance and blood parameters of male goat kids fed EasiFlo ${ }^{\circledR}$ cottonseed. Small Rumin. Res. 81:137-145.

Sunagawa, K., T. Ooshiro, N. Nakamura, Y. Ishii, I. nagamine, and A. Shinjo. 2007. Physiological factors depressing feed intake and saliva secretion on goats fed on dry forage. Asian-Aust. J. Anim. Sci. 20:60-69.

Takaya, Y., T. Furukawa, S. Miura, T. Akutagawa, Y. Hotta, N. Ishikawa, and M. Niwa. 2007. Antioxidant Constituents in Distillation Residue of Awamori Spirits. J. Agric. Food Chem. 55:75-79.

Tamaki, M., H. Shimabukuro, S. Okano, and T. Namihira. 2005. The availability of Awamori-moromi vinegar residues as the dairy cattle feed. The West Japan Journal of Animal Science 48:65-67.

Thang, T. V., K. Sunagawa, I. Nagamine, T. Kishi, and G. Ogura. 2012. The main suppressing factors of dry forage intake in large-type goats. Asian-Aust. J. Anim. Sci. 25:341-352.

Yamasaki, T., T. Aki, M. Shinozaki, M. Taguchi, S. Kawamoto, and K. Ono. 2006. Utilization of Shochu distillery wastewater for production of polyunsaturated fatty acids and xanthophylls using thraustochytrid. J. Biosci. Bioeng. 102:323-327.

Zhang, J. L. Villacorta, L. Chang, Z. Fan, M. Hamblin, T. Zhu, C. S. Chen, M. P. Cole, F. J. Schopfer, C. X. Deng, M. T. GarciaBarrio, Y. H. Feng, B. A. Freeman, and Y. E. Chen. 2010. Nitro-oleic acid inhibits angiotensin II-induced hypertension. Circ. Res. 107:540-548. 